\title{
COMPARISON OF AEROBIC PERFORMANCE INDICATORS OF SOCCER AND FUTSAL ATHLETES
}

\author{
COMPARAÇÃO DE INDICADORES DE DESEMPENHO AERÓBICO DE ATLETAS DE FUTEBOL EFUTSAL
}

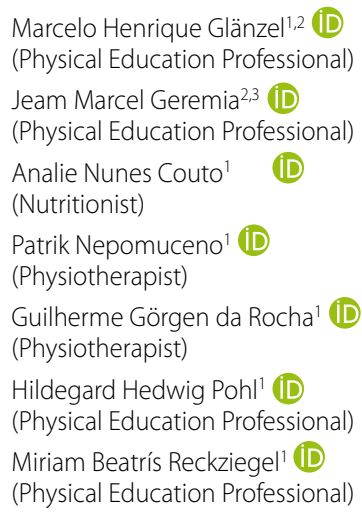

1. Universidade de Santa Cruz do Sul, Department of Physical Education and Health, Physical Activity and Health Laboratory, Santa Cruz do Sul, RS, Brazil. 2. Universidade Federal de Santa Maria, Center for Physical Education and Sports, Biomechanics Laboratory, Santa Maria, RS, Brazil.

3. Universidade Federal do Rio Grande do Sul, School of Physical Education, Physiotherapy and Dance, Exercise Research Laboratory, Porto Alegre, RS, Brazil.

\section{Correspondence:}

Marcelo Henrique Glänzel. Universidade de Santa Cruz do Sul (UNISC). Avenida Independência, 2293 - Prédio 42, Bairro Universitário. 96815900. Santa Cruz do Sul, RS, Brazil. marceloglanzel8@hotmail.com

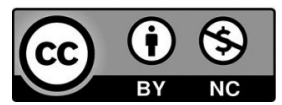

\begin{abstract}
Soccer and futsal have similar technical movements that are used within different spatial dimensions and game dynamics. The possible physiological differences between players of each sport were unknown. The main purpose of this study was to compare the maximum oxygen uptake $\left(\mathrm{VO}_{2} \mathrm{max}\right)$ and ventilatory thresholds $(V T)$ of soccer and futsal players. $\mathrm{VO}_{2}$ max and VT of 32 athletes (soccer: $n=15$; futsal: $n=17$ ) were obtained by ergospirometry in a progressive treadmill test. $\mathrm{VO}_{2}$ max was similar between groups. VT occurred later and at higher running speeds in the soccer players. The similarities found in $\mathrm{VO}_{2}$ max may be related to the fact that the evaluations were carried out in the pre-season. The fact that the VT was reached later in the soccer players suggests a longer capacity for aerobic exercise and greater resistance to lactate production. Moreover, soccer players appear to be conditioned to withstand increased running times and speeds, until exhaustion. Players of both sports reached the second VT at similar intensities, suggesting no prevalence of anaerobic metabolism. Soccer and futsal players have similar $\mathrm{VO}_{2}$ max, but their VTs occur at different times, and at different running speeds. Level of Evidence III; Cross-sectional study.
\end{abstract}

Keywords: Soccer; Oxygen consumption; Athletes.

\section{RESUMO}

O futebol e o futsal têm movimentos técnicos semelhantes que são utilizados em distintas dimensões espaciais e dinâmicas de jogo. As possíveis diferenças fisiológicas entre as modalidades não foram esclarecidas. O objetivo do presente estudo foi comparar o consumo máximo de oxigênio $\left(\mathrm{VO}_{2 \text { máx }}\right)$ e os limiares ventilatórios ( $(\mathrm{VV})$ de atletas de

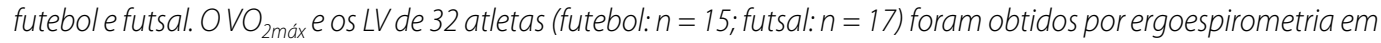

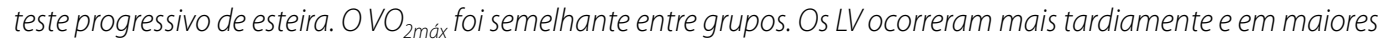
velocidades nos atletas de futebol. A semel hança encontrada nos valores de $\mathrm{VO}_{2 \text { máx }}$ pode estar relacionada com as avaliações terem sido realizadas em pré-temporada. A obtenção tardia dos LV em atletas de futebol sugere maior permanência em exercício aeróbico e maior resistência à produção de lactato. Além disso, parecem estar condicionados ao fato de suportarem maiores tempos evelocidades de corrida até chegarem à exaustão. Entretanto, ambas as modalidades atingiram o segundo LV em intensidades semelhantes, sugerindo não haver prevalência do metabolismo anaeróbico. Atletas de futebol e futsal apresentam VO ${ }_{2 \text { máx }}$ similares, embora os LVocorram em momentos distintos e com diferentes velocidades de corrida. Nível de evidência III; Estudo transversal comparativo.

Descritores: Futebol; Consumo de oxigênio; Atletas.

\section{RESUMEN}

El fútbol y el futsal tienen movimientos técnicos semejantes que son usados en distintas dimensiones espaciales y dinámicas de juego. Las posibles diferencias fisiológicas entre las modalidades no fueron esclarecidas. El objetivo del presente estudio fue comparar el consumo máximo de oxígeno $\left(\mathrm{VO}_{2}\right.$ máx) y los umbrales ventilatorios (UV) de atletas de fútbol y futsal. El VO $\mathrm{O}_{2}$ máx y los UV de 32 atletas (fútbol: $n=15$; futsal: $n=17$ ) fueron obtenidos por ergoespirometría en test progresivo de cinta. El VO ${ }_{2}$ máx fue semejante entre grupos. Los UV ocurrieron más tardiamente y en mayores velocidades en los atletas de fútbol. La semejanza encontrada en los valores de $\mathrm{VO}_{2}$ máx puede estar relacionada con que las evaluaciones hayan sido realizadas en pretemporada. La obtención tardía de los UV en atletas de fútbol sugiere mayor permanencia en ejercicio aeróbico y mayor resistencia a la producción de lactato. Además, parecen estar condicionados al hecho de soportar mayores tiempos y velocidades de carrera hasta llegar al agotamiento. Entretanto, ambas modalidades alcanzaron el segundo UV en intensidades semejantes, sugiriendo no haber prevalencia del metabolismo anaeróbico. Atletas de fútbol y futsal presentan $\mathrm{VO}_{2}$ máx similares, aunque los UV ocurran en momentos distintos y con diferentes velocidades de carrera.

Nivel de evidencia III; Estudio transversal comparativo.

Descriptores: Fútbol; Consumo de oxígeno; Atletas. 


\section{INTRODUCTION}

Soccer is a field sport with various movements and movement patterns required from players (e.g. shorts and long sprints, walking and running slowly, accelerations with rapid decelerations, changes in direction, jumps, kicks, and confrontations). ${ }^{1,2}$ Futsal is similar to soccer, but it is played on a smaller court, with fewer players, uses a smaller ball, and allows for constant and unlimited substitutions. ${ }^{3-6}$ Futsal is a dynamic and intense sport that requires many movements within short periods. ${ }^{3,5,7}$

Various studies have compared the physiological characteristics of soccer and futsal players. ${ }^{5,7-11}$ Maximum oxygen uptake $\left(\mathrm{VO}_{2} \mathrm{max}\right)$ and ventilatory threshold (VT) are two characteristics that are commonly used to measure athletes'fitness. $\mathrm{VO}_{2}$ max is an indicator of the highest oxygen uptake $\left(\mathrm{VO}_{2}\right)$ per unit of time that an individual can capture, transport and use at the cellular level. ${ }^{8} \mathrm{VT}$ is an indicator of lactate production and includes a first and second threshold. ${ }^{12} \mathrm{VO}_{2}$ max is a determinant factor for aerobic capacity ${ }^{13}$ and is considered the gold standard for assessing aerobic fitness. $\mathrm{VO}_{2}$ max seems to be a determinant in soccer performance, ${ }^{13,14}$ but not as much in futsal performance. ${ }^{5}$ The literature contains contradictory data, where studies have found higher $\mathrm{VO}_{2}$ max in soccer, ${ }^{7}$ or futsal players, ${ }^{5}$ and have also observed similarities. ${ }^{8,10}$ These different outcomes can be attributed to factors ranging from different evaluation periods during the season, level of competitiveness and evaluation protocols.

$\mathrm{VT}$ is a measure of endurance performance. The first VT threshold $\left(V T_{1}\right)$ corresponds to the start of blood lactate accumulation, and the second threshold $\left(\mathrm{VT}_{2}\right)$ to the moment when lactate production exceeds its removal. ${ }^{9}$ Studies comparing VTs of soccer and futsal players ${ }^{5,8-10}$ have related $\mathrm{VT}$ to $\mathrm{VO}_{2}$ at the time of $\mathrm{VT}_{2},{ }^{5,9}$ and the percentage of $\mathrm{VO}_{2}$ max during $\mathrm{VT}_{2}\left(\mathrm{VVO}_{2} \mathrm{maxVT}_{2}\right){ }^{9},{ }^{9}{ }^{15}$ Soccer players reached $\% \mathrm{VO}_{2} \mathrm{maxVT}_{2}$ between 76.6 and $90.3 \%$ and futsal players between 65 and $77 \%,{ }^{9}$ demonstrating that $V T_{2}$ occurred at different exercise intensities. ${ }^{10}$ The percentage of $\mathrm{VO}_{2}$ max during $\mathrm{VT}_{1}\left(\% \mathrm{VO}_{2} \mathrm{maxVT}_{1}\right)$ is rarely reported in the literature $\mathrm{e}^{16,17}$ even though it is an indicator of aerobic metabolism ${ }^{16}$ that marks the beginning of lactate accumulation. ${ }^{18}$ Running speed during each VT is also a parameter of exercise intensity ${ }^{9,18}$, and when running speed is associated with $\mathrm{VO}_{2}$ max and $\mathrm{VT}$ it can provide more information than isolated cardiorespiratory variables. ${ }^{11,15,19}$ Studies evaluating running speed during $V T_{1}$ (speed $V T_{1}$ ), ${ }^{9}$ and $V T_{2}$ (speed $V T_{2}$ ) ${ }^{5,8,9}$ have found contradictory results, where: speedVT, was superior in futsal players; ${ }^{9}$ speedVT 2 was superior in soccer players, and; ${ }^{8}$ speed $\mathrm{VT}_{2}$ was similar in soccer and futsal players. ${ }^{9}$ These contradictory outcomes could result from a lack of control in training stage between soccer and futsal players. This study aimed to compare the $\mathrm{VO}_{2}$ max and VT of soccer and futsal players at the same training stage during the start of the preseason. We hypothesized that: 1) soccer players would have higher $\mathrm{VO}_{2}$ max than futsal players; ${ }^{7}$ and 2) $V T_{1}$ and $V T_{2}$ would occur earlier in futsal players than soccer players. ${ }^{9}$

\section{MATERIALS AND METHODS}

\section{Participants}

This study was approved by the institutional Research Ethics Committee of the University of Santa Cruz do Sul, RS, Brazil (number 1.514.711). All participants read and signed an informed consent form.

Study participants were State level male soccer and futsal players who met the inclusion criteria: a) aged 18 to 30 years old; $b$ ) no musculoskeletal injuries; c) no respiratory disorders; and d) no heart disease. Individuals who did not reach $\mathrm{VT}_{2}$ during testing and those who had difficulties understanding the experimental protocol were excluded from the study. Thirty-two athletes (soccer: $n=15$; futsal: $n=17$ ) participated in the study.

The evaluation took place preseason, prior to any soccer or futsal training. During the evaluation period, soccer and futsal players began their preparation to compete in the State championships.
To characterize athletes, body mass and height were measured. Measurements followed Heyward's guidelines using a beam scale (Welmy R110; Welmy SA, Santa Bárbara do Oeste, Brazil). ${ }^{20}$

\section{Assessment of performance indicators}

Cardiorespiratory parameters were obtained by ergospirometry during a maximal effort test on a treadmill (Super ATL, Inbramed Ltda., Porto Alegre, RS, Brazil). The Bruce ramp protocol was used, which consists of seven three-minute stages. The starting speed and inclination were $2.7 \mathrm{~km} / \mathrm{h}$ and $10^{\circ}$, respectively. Each progressive stage involved an increase in speed and inclination of $1.6 \mathrm{~km} / \mathrm{h}$ and 20.21,22 Respiratory gases were measured every 20 seconds by a gas analyzer (VO2000, Aerosport, Medgraphics, St. Paul, Minnesota, USA), which was calibrated before the start of each test within a temperature-controlled environment $\left(20-22^{\circ} \mathrm{C}\right)$. Assessments were performed during the day, with all subjects in a resting state (sitting for five minutes) until the time of the test. The test duration was determined by the athletes' voluntary exhaustion; when the athletes reached their effort limit, the test was immediately interrupted, and the recovery phase began [three minutes of walking on the treadmill at $2.7 \mathrm{~km} / \mathrm{h}$ without any inclination $\left(0^{\circ}\right)$ ].

$\mathrm{VO}_{2}$ max was determined by the $\mathrm{VO}_{2}$ peak reached during the maximal effort test. ${ }^{23}$ It was captured in absolute and relative values, but only relative values were reported. VTs were identified by three experienced evaluators using the visual-graphic method, which consists of observing the behaviour of the $\mathrm{VO}_{2}$ curve (oxygen consumption over time) and the production of carbon dioxide $\left(\mathrm{VCO}_{2}\right)$ during progressive effort. $\mathrm{VT}_{1}$ was identified when the $\mathrm{VCO}_{2}$ increased disproportionately to $\mathrm{VO}_{2}$ (i.e. loss of parallelism), while $\mathrm{VT}_{2}$ was identified at the time of respiratory compensation or during the disproportionate increase in ventilation compared to $\mathrm{VCO}_{2}{ }^{17,23}$ For $\mathrm{VT}_{1}$ or $\mathrm{VT}_{2}$, when the three evaluators identified identical values, that value was adopted. In the case of divergences between evaluators, the median result was chosen.

Each VT was calculated relative to $\mathrm{VO}_{2} \max \left(\% \mathrm{VO}_{2} \mathrm{maxVT}_{1} ; \% \mathrm{VO}_{2} \mathrm{ma}-\right.$ $\mathrm{xV} \mathrm{T}_{2}$ ), acquisition time of $\mathrm{VT}$ (in $\min$ ), $, 15,24$ and running speed on the treadmill (speed $V T_{1}$; speed $V T_{2}$ )., 9,24

\section{Statistical analysis}

Descriptive analyses (mean and standard deviation) were performed. The normality of the data was verified by the Shapiro-Wilk test. Betweengroup comparisons were performed using Student's t-test for independent samples (parametric data), or the Mann-Whitney U test (non-parametric data). All statistical tests were performed using SPSS software (v. 23.0; IBM Corporation, Armonk, New York, NY, USA), with $a=0.05$.

\section{RESULTS}

The characterization of the players is shown in Table 1. Regarding positions, soccer players included a goalkeeper, a full-back, four defenders, four defensive midfielders, three midfielders, and two forwards. Futsal players included two goalkeepers, four defenders, nine wingers, and two pivots. The groups were similar in terms of age and body mass; however, soccer players were taller.

No differences were found in $\mathrm{VO}_{2}$ max and $\% \mathrm{VO}_{2} \mathrm{maxVT}_{2}$ between groups but soccer players had higher $\% \mathrm{VO}_{2}$ maxVT, $\mathrm{VT}_{1}$ and $V \mathrm{~T}_{2}$. In addition, futsal players reached both VTs at lower speeds (Table 2).

Table 1. Characterization of groups of players

\begin{tabular}{c|c|c|c}
\hline & Soccer & Futsal & p \\
\hline Age (years) & $25.60 \pm 3.18$ & $26.82 \pm 2.92$ & 0.266 \\
\hline Mass $(\mathrm{kg})$ & $79.32 \pm 7.35$ & $75.76 \pm 8.10$ & 0.206 \\
\hline Height $(\mathrm{m})$ & $1.77 \pm 0.06$ & $1.72 \pm 0.05$ & $0.022^{*}$ \\
\hline
\end{tabular}


Table 2. Cardiorespiratory variables of soccer and futsal players.

\begin{tabular}{|c|c|c|c|}
\hline & Soccer & Futsal & $\mathrm{p}$ \\
\hline $\mathrm{VO}_{2} \max \left(\mathrm{ml} \mathrm{kg}^{-1} \cdot \mathrm{min}^{-1}\right)$ & $39.80 \pm 6.86$ & $36.97 \pm 5,84$ & 0,219 \\
\hline $\mathrm{VO}_{2} \mathrm{maxVT}_{1}(\%)$ & $62.81 \pm 15.29$ & $50.68 \pm 10.64$ & $0.013^{*}$ \\
\hline $\mathrm{VT}_{1}(\min )$ & $9.15 \pm 2.08$ & $5.50 \pm 1.02$ & $0.000^{*}$ \\
\hline SpeedVT, $(k m / h)$ & $6.44 \pm 1.00$ & $4.49 \pm 0.68$ & $0.000^{*}$ \\
\hline $\mathrm{VO}_{2} \mathrm{maxVT}_{2}(\%)$ & $91.65 \pm 7.29$ & $86.19 \pm 11.72$ & 0.130 \\
\hline $\mathrm{VT}_{2}(\min )$ & $15.10 \pm 2.61$ & $12.02 \pm 1.42$ & $0.000^{*}$ \\
\hline SpeedVT $_{2}(\mathrm{~km} / \mathrm{h})$ & $8.42 \pm 0.73$ & $7.31 \pm 0.81$ & $0.001^{*}$ \\
\hline
\end{tabular}

Values expressed as mean and standard deviation $( \pm)_{;} \mathrm{VO}_{2} \mathrm{max}=$ maximal oxygen uptake; $\% \mathrm{VO}_{2} \mathrm{maxVT}_{1}=$ percentage of $\mathrm{VO}_{2}$ max at first ventilatory threshold; $\mathrm{VT}_{1}=$ first ventilatory threshold; speedVT $T_{1}=$ speed during first $\mathrm{VT}$; $\% \mathrm{VO}_{2}$ maxVT $_{2=}$ percentage of $\mathrm{VO}_{2}$ max at second ventilatory threshold; $\mathrm{VT}_{2}=$ second ventilatory threshold; speedVT $=$ speed during second $\mathrm{VT} .{ }^{*}$ = statistically significant differences between groups $(\mathrm{p} \leq 0.05)$.

\section{DISCUSSION}

This study aimed to compare aerobic performance indicators between soccer and futsal players. No differences were found in $\mathrm{VO}_{2}$ max and \%VO${ }_{2} \mathrm{maxVT}_{2}$ between groups. Percent $\mathrm{VO}_{2} \mathrm{maxVT}_{1}$ was lower in futsal players, and their VT occurred sooner and at lower speeds than in soccer players.

$\mathrm{VO}_{2}$ max represents the maximal capacity of oxygen consumption and reflects level of fitness. We found no differences in $\mathrm{VO}_{2}$ max between soccer and futsal players. These results agree with previous studies that controlled for stage of training. ${ }^{8-10}$ Soccer and futsal players may have similar $\mathrm{VO}_{2}$ max levels due to the intermittent high-intensity nature of their sports. ${ }^{4}$ Contradictory values of $\mathrm{VO}_{2}$ max were identified between soccer and futsal players in studies that did not control for stage of training. Karimi, Hojjati and Shamsi ${ }^{7}$ found higher $\mathrm{VO}_{2}$ max values in soccer players $\left(57.42 \mathrm{ml} \cdot \mathrm{kg}^{-1} \cdot \mathrm{min}^{-}{ }^{-}\right)$ than futsal players $\left(52.77 \mathrm{ml} \cdot \mathrm{kg}^{-1} \cdot \mathrm{min}^{-}\right)$. According to the authors, this suggests an aerobic predominance in soccer, where the aerobic system is the main source of energy (70 to 90\%) during a match/ training., ${ }^{5,10,25} \mathrm{VO}$ ${ }_{2}$ max is linked to the distance covered during a match; thus, soccer players may have better endurance, withstanding longer periods of exercise until exhaustion. ${ }^{8}$ On the other hand, Nunes et al. ${ }^{5}$ found a higher $\mathrm{VO}_{2}$ max in futsal players $\left(62.5 \mathrm{ml} \cdot \mathrm{kg}^{-1} \cdot \mathrm{min}^{-1}\right)$ than in soccer players $\left(52.1 \mathrm{ml} \cdot \mathrm{kg}^{-1} \cdot \mathrm{min}^{-}\right)$. These authors attributed their results to the different training methods, levels of competitiveness and number of competitions between players. Therefore, the level of competitiveness of the teams may have influenced the results, as the futsal team in their study competed nationally while the soccer team competed at the state level. Since $\mathrm{VO}_{2}$ max may vary during the season (3-7\% lower at the beginning of the season than the end) ${ }_{1}^{13}$ it is important to consider evaluation period, periodization of training, and level of competitiveness of players when different sports are compared.

$\mathrm{VT}_{1}$ refers to the beginning of lactate accumulation during physical effort. ${ }^{18}$ In our study, futsal players reached $V_{1}$ at lower percentages of $\mathrm{VO}_{2}$ max, and it occurred earlier and at lower speeds than in soccer players, suggesting earlier lactate production in futsal players. This may result from greater participation of anaerobic glycolytic metabolism in futsal players, while aerobic metabolism is still their main source of energy. ${ }^{16}$ Despite this, $V T_{1}$, which represents intensity of effort relative to $\mathrm{VO}_{2}$ max, was lower in futsal than in soccer players and futsal players had a longer interval between $\mathrm{VT}_{1}$ and $\mathrm{VT}_{2}$. According to Wilke et al., ${ }^{17}$ intensity is divided into three zones: below $V T_{1}$ (low intensity), between $V T_{1}$ and $V T_{2}$ (moderate intensity), and above $\mathrm{VT}_{2}$ (high intensity). It is reported that futsal players expend $73 \%$ of a training session below $\mathrm{VT}_{1}, 20 \%$ between the $\mathrm{VT}_{1}$ and $\mathrm{VT}_{2}$ and $7 \%$ above $\mathrm{VT}_{2} \cdot{ }^{17}$, while soccer players cover approximately $11 \mathrm{~km}$ in a match, with $3 \%$ and $5 \%$ of a training session spent sprinting and running at high-intensity effort, respectively. ${ }^{26}$ Therefore, it is expected that futsal players have higher speeds during VT, since speedVT is highly correlated to the ability to perform repeated high-intensity sprints over time. ${ }^{24}$ Contrary to our results, Ribeiro et al. ${ }^{9}$ observed a higher speedVT ${ }_{1}$ in futsal players $(13.3 \mathrm{~km} / \mathrm{h})$ than soccer players $(11.0 \mathrm{~km} / \mathrm{h})$; however, this study did not control for preseason period (initial and final). Ribeiro et al. ${ }^{9}$ also adopted a more intense ramp protocol with an increase in speed of $1 \mathrm{~km} / \mathrm{h}$ every minute, where testing lasted between 8-12 minutes, while we adopted a longer protocol (i.e. Bruce protocol) with increases in speed and inclination of $1.6 \mathrm{~km} / \mathrm{h}$ and $2^{\circ}$ at each 3-min stage, lasting up to 21 minutes.

$\mathrm{VT}_{2}$ represents the respiratory compensation point. ${ }^{18} \mathrm{We}$ found no differences in $\% \mathrm{VO}_{2} \mathrm{maxVT}_{2}$ between soccer and futsal players. This is in agreement with the results of Baroni et al. ${ }^{8}$, who observed $\% \mathrm{VO}_{2} \mathrm{maxVT}_{2}$ at similar intensities (soccer $=87.89 \%$; futsal $=88.29 \%$ ). Nunes et al. ${ }^{5}$ found higher $\% \mathrm{VO}_{2} \mathrm{maxVT}_{2}$ in futsal players (futsal $=93.9 \%$; soccer $=76 \%$ ), who reached $\mathrm{VT}_{2}$ at higher intensities than soccer players. Our results may have been different from Nunes et al. ${ }^{5}$ because our evaluations were performed at the beginning of the preseason, while Nunes et al. ${ }^{5}$ did not mention the phase of the preseason in which players were evaluated. In our study, $V T_{2}$ was reached earlier (less time) in futsal than soccer players. Leal Junior et al. ${ }^{10}{ }^{10}$ also found that futsal players reached $\mathrm{VT}_{2}$ earlier (11.4 min) than soccer players (14.0 min), suggesting that soccer players have a greater aerobic capacity. Like Baroni et al., ${ }^{8}$ we found that speedVT 2 was greater in soccer players than futsal players. Soccer players reached both VTs at higher speeds (equivalent to time/test stage), where $\mathrm{VO}_{2}$ increases as running speed increases, ${ }^{27}$ suggesting that soccer players can withstand progressive effort for longer periods until exhaustion. ${ }^{8}$

Our study had some limitations. Laboratory effort protocols, such as the one used in this study, are not very functional for soccer and futsal, while field tests have good applicability. ${ }^{28,29}$ However, the procedures used in this study can be performed with athletes to assess basic physiological parameters (e.g. $\mathrm{VO}_{2}$ max and $\mathrm{VT}$ ), which assist in building highly specific training programs. ${ }^{22,29}$ Participants in our study were not stratified by position, which could have minimized intragroup variation as there are different mechanical and physiological demands for each position. 8,18,30 However, the number of players evaluated did not allow for such stratification. To control these limitations, pre-training and post-training evaluations could be performed, and training routines and game calendars could be monitored. ${ }^{18}$ This would allow us to identify adaptations to physiological parameters caused by training. ${ }^{31}$ As well, the inclusion of other physiological markers such as blood lactate, ${ }^{4,15,32}$ heart rate, 2,5 and subjective perception of effort, ${ }^{31,33}$ could provide additional information about the demands of soccer and futsal and the physiological profiles of players.

\section{CONCLUSION}

In the preseason phase of the competitive calendar of soccer and futsal, male players have similar $\mathrm{VO}_{2}$ max's and reach their $V T$ at different times and speeds. Different levels of physical effort and physiological adaptations exist for each sport, indicating that training methods should be designed with each sport's specificity in mind.

All authors declare no potential conflict of interest related to this article

\footnotetext{
AUTHORS' CONTRIBUTIONS: Each author made significant individual contributions to this manuscript. MHG: substantial contribution to the conception and design of the work, analysis and interpretation of the data, writing the manuscript and preparing the final version of the manuscript; JMG: interpretation of the data, writing the manuscript, critical review of the intellectual content and final approval of the version of the manuscript; ANC: analysis and interpretation of the data, writing the manuscript and critical review of the intellectual content; PN: analysis and interpretation of the data, writing the manuscript and preparing the final version of the manuscript; GGR: substantial contribution to the concept and design of the work, analysis of the data; HHP): substantial contribution to the concept and design of the work, critical review of its intellectual content and final approval of the version of the manuscript. MBR: substantial contribution to the concept and design of the work, interpretation of the data, critical review of its intellectual content and final approval of the version of the manuscript.
} 


\section{REFERENCES}

1. Powers SK, Howley ET. Fisiologia do exercício: teoria e aplicação ao condicionamento e ao desempenho. 8th ed. Barueri, SP: Manole; 2014

2. Oliveira RS, Pedro RE, Milanez VF, Bortolotti H, Costa MV, Nakamura FY. Relação entre variabilidade da frequência cardíaca e aumento no desempenho físico em jogadores de futebol. Rev Bras Cineantropom Desempenho Hum. 2012;14(6):713-722

3. Ferreira AP, Gomes SA, Gonçalves HR, de França NM. Composição corporal, limiar anaeróbio e consumo máximo de oxigênio de atletas de futsal: analise descritiva entre as posições. Rev Bras Ciên Mov. 2009;16(3):41-49

4. Gorostiaga EM, Llodio I, Ibáñez J, Granados C, Navarro I, Ruesta M, et al. Differences in physical fitness among indoor and outdoor elite male soccer players. Eur J Appl Physiol. 2009;106(4):483-491.

5. Nunes RFH, Almeida FAM, Santos BV, Almeida FDM, Nogas G, Elsangedy HM, et al. Comparação de indicadores físicos e fisiológicos entre atletas profissionais de futsal e futebol. Motriz Rev Educ Fis. 2012;18(1):104-112.

6. Nunes R, Buzzachera C, Almeida F, DA Silva JF, Flores L, DA Silva SG. Relationships between isokinetic muscle strength, measures of aerobic fitness, single sprint performance, and repeated sprint ability in elite futsal players. Gazz Med Ital - Arch Sci Med. 2016;175(5):205-213.

7. Karimi S, Hojjati Z, Shamsi A. Comparison the anthropometric and physical fitness characteristics of rasht city semiprofessional soccer and futsal players. Euro J Phys Educ Sport. 2015;9(3):146-150.

8. Baroni BM, Couto W, Leal Junior ECP. Estudo descritivo-comparativo de parâmetros de desempenho aeróbio de atletas profissionais de futebol e futsal. Rev Bras Cineantropom e Desempenho Hum. 2011;13(3):170-176

9. Ribeiro FC, Almeida TL, Guedes Jr DP, Mineiro AS, Scorcine CR, Barbosa FM, et al. Características fisiológicas e antropométricas de atletas profissionais de futebol e futsal. Rev Bras Futebol e Futsal. 2017;9(32):21-26.

10. Leal Junior ECP, Souza FdB, Magini M, Martins RÁBL. Estudo comparativo do consumo de oxigênio e limiar anaeróbio em um teste de esforço progressivo entre atletas profissionais de futebol e futsal. Rev Bras Med Esporte. 2006;12(6):323-326.

11. Silva J, Detanico D, Floriano LT, Dittrich N, Nascimento PC, Santos S, et al. Níveis de potência muscular em atletas de futebol e futsal em diferentes categorias e posições. Motricidade. 2012;8(1):14-22.

12. Mehmet S, Selcen KE, Metin P, Sami A. Comparison of maximal oxygen uptake and anaerobic threshold in soccer and handball players. Physical Education of Students. 2017;21(4):171-5.

13. Slettaløkken G, Rønnestad BR. High-intensity interval training every second week maintains $\mathrm{VO}_{2}$ max in soccer players during off-season. J Strength Cond Res. 2014;28(7):1946-1951

14. Marcos MA, Koulla PM, Anthos ZI. Preseason maximal aerobic power in professional soccer players among different divisions. J Strength Cond Res. 2018;32(2):356-363.

15. Bosquet L, Léger L, Legros P. Methods to determine aerobic endurance. Sports Med. 2002;32(11):675-700

16. Crisp AH, Verlengia R, Gonsalves Sindorf MA, Germano MD, de Castro Cesar M, Lopes CR. Time to exhaustion at $\mathrm{VO}_{2}$ max velocity in basketball and soccer athletes. J Exerc Physiol Online. 2013;16(2):82-91.

17. Wilke CF, Ramos GP, Pacheco DA, Santos WH, Diniz MS, Gonçalves GG, et al. Metabolic demand and internal training load in technical-tactical training sessions of professional futsal players. J Strength Cond Res. 2016;30(8):2330-2340.

18. Baroni BM, Piccoli RB, Leal Junior ECP. Influência do nível competitivo e da posição tática sobre parâmetros de desempenho aeróbio de atletas profissionais de futebol do Brasil. Rev Bras Educ Fís Esporte. 2013;27(2):199-207.

19. Naser N, Ali A, Macadam P. Physical and physiological demands of futsal. J Exerc Sci Fit. 2017;15(2):76-80.

20. Heyward VH. Avaliação física e prescrição de exercício: técnicas avançadas. 6th ed. Porto Alegre: Artmed; 2013.

21. Gligoroska JP, Manchevska S, Efremova L, Todorovska L, Nikolic S. Body composition and maxima oxygen consumption in adult soccer players in the Republic of Macedonia.J Health Sci. 2015;5(3):85-92.

22. Sarma S, Levine BD. Beyond the Bruce protocol: advanced exercise testing for the sports cardiologist. Cardiol Clin. 2016;34(4):603-608.

23. Herdy AH, Ritt LEF, Stein R, Araújo CGSd, Milani M, Meneghelo RS, et al. Cardiopulmonary exercise test: background, applicability and interpretation. Arq Bras Cardiol. 2016;107(5):467-481.

24. Pedro RE, Milanez VF, Boullosa DA, Nakamura FY. Running speeds at ventilatory threshold and maximal oxygen consumption discriminate futsal competitive level. J Strength Cond Res. 2013;27(2):514-518.

25. Boraczyński M, Boraczyński T, Podstawski R, Wójcik Z. Relationships between anthropometric traits, body composition and aerobic capacity in male soccer players aged 13-15 years. J Kinesiology Exer Sci. 2015;69(25):33-40.

26. Rodríguez-Fernández A, Sanchez-Sanchez J, Ramirez-Campillo R, Nakamura FY, Rodríguez-Marroyo JA, Villa-Vicente JG. Relationship between repeated sprint ability, aerobic capacity, intermittent endurance, and heart rate recovery in youth soccer players. J Strength Cond Res. 2019;33(12):3406-3413.

27. Billat LV, Koralsztein JP. Significance of the velocity at $\mathrm{VO}_{2}$ max and time to exhaustion at this velocity. Sports Med. 1996;22(2):90-108.

28. Nunes RFH, Danieli AV, Flores LJF, Coelho TM, Cetolin T, Carminatti LJ, et al. Potência aeróbia em atletas de futebol e futsal de diferentes níveis competitivos. Rev Bras Ciênc Mov. 2017;25(4):5-14

29. Dittrich N, da Silva JF, Castagna C, de Lucas RD, Guglielmo LGA. Validity of Carminatti's test to determine physiological indices of aerobic power and capacity in soccer and futsal players. J Strength Cond Res. 2011;25(11):3099-3106

30. Júnior MC, Arantes FJ, Araújo HN, Paixão RC, Bertucci DR, Resende WB, et al. Comparação do consumo máximo de oxigênio entre jogadores de futsal que atuam em diferentes posições. Rev Bras Futebol e Futsal. 2014;6(20).

31. Matzenbacher F, Pasquarelli B, Rabelo F, Stanganelli LCR. Demandas fisiológicas del futsal de competición: características físicas y fisiológicas de jugadores profesionales. Rev Andal Med Deporte. 2014;7(3):122-131.

32. Silva PRS, Romano A, Teixeira AAA, Visconti AM, Roxo CDMN, Machado GS, et al. A importância do limiar anaeróbio e do consumo máximo de oxigênio $\left(\mathrm{VO}_{2}\right.$ máx.) em jogadores de futebol. Rev Bras Med Esporte. 1999;5(6):225-232

33. McLaren SJ, Smith A, Spears IR, Weston M. A detailed quantification of differential ratings of perceived exertion during team-sport training. J Sci Med Sport. 2017;20(3):290-295 